\title{
Getting it Right with Health: Foreign Direct Investment as Africa's Best Chance to Achieve the Health Targets of Agenda 2030 Sustainably?
}

\author{
Uchechukwu Ngwaba \\ Law School, Macquarie University \\ uche.ngwaba@gmail.com
}

\begin{abstract}
Of the seventeen Sustainable Development Goals 2030, SDG 3 relates specifically to health and is framed in deliberately broad terms to be relevant to all countries and populations. It aims to 'ensure healthy lives and promote well-being for all ages'. Health target 3.8, one of thirteen health targets associated with SDG 3, speaks directly to Africa's experience with pharmaceuticals and public health. This article considers whether foreign direct investment (FDI) offers the best chance for the attainment of these targets - and concludes that it does not. Engaging the critical lens of third world approaches to international law (TWAIL), this article argues for the recalibration of Africa's approach to Agenda 2030 through nuanced engagement with the right to health. It suggests that a uniquely African perspective needs to inform Africa's approach to FDI, one that takes account of the peculiar needs of African people in the area of health by cultivating African human capital and entrepreneurial potential as a viable alternative to FDI. Strengthening local capital in this manner offers a better chance for sustainably achieving the health targets of SDG 3.
\end{abstract}

\section{Introduction}

One thing is clear, Africa needs to develop a unique strategy for achieving the Sustainable Development Goals 2030 (SDGs), particularly in the area of health where the continent is seriously lagging behind (World Health Organisation 2015). Of course there are other areas where the continent can improve on its record, including the economy, education and human capital development where Africa needs to experience a paradigm shift. However, health stands out because the cost of failure is serious as it affects the wellbeing of African people immediately. Health also stands out because the health-related SDGs join earlier initiatives championed by the World Health Organisation (WHO) and other global health institutions, including the 
primary health care approach of the Alma Ata Declaration (World Health Organisation \& United Nations Children's Fund 1978), and the health targets of the Millennium Development Goals (MDGs) (World Health Organisation 2014). In all instances, despite high expectations of radical improvements in the health sector, many countries on the African continent were unable to meet set targets. Mainly for these reasons focus has now been brought to bear on how Africa can get it right with health in the agenda of the SDGs 2030.

While the article appears to treat Africa as a monolith, it is clear that the continent is divided along geographical, economic, ethnic, cultural and other lines. It is difficult to offer sweeping solutions to the needs of the continent on many issues. Nonetheless, the entire continent is united behind the shared need for "complete physical, mental and social well-being" (WHO Constitution 1946), albeit with emphasis on different areas of health needs. We thus consider how the continent as a whole can situate itself in the bid to secure the health targets of SDG 3.

In pushing for a unique strategy to achieve the targets of SDG 3 sustainably, the continent's approach to the growth of its economies assumes a central place. In particular, it remains to be decided whether it is better to focus on foreign direct investment as the key strategy to achieve sustainable, all-inclusive economic growth; or whether emphasis should shift to cultivating local entrepreneurial potentials as a viable alternative to FDI, with a long term view to improving the underlying determinants of health. Taking into account the underlying determinants of health (United Nations, Office of the High Commissioner for Human Rights 2000) goes beyond the narrow focus on clinical outcomes inferable from SDG 3.8, and suggests, as other scholars have argued, that the fulfilment of the right to health should account for the priorities of SDG 3.8 (and other health targets in SDG 3) (Forman 2016; Ooms et al., 2013).

At first glance the connection between economic considerations, such as FDI, and the health targets of SDG 3 escapes the eye. Critical scrutiny, however, reveals economic considerations as vital to any serious initiative to achieve these health targets sustainably before the cut-off date of 2030 . Informed by the critical scholarship of third world approaches to international law (TWAIL) (Gathii 2011), which necessitates a sceptical view of the underlying motives of foreign capital on the African continent, the article argues that a uniquely African perspective needs to inform Africa's approach to FDI and to take account of the peculiar needs of African people in the area of health. Such a perspective needs to cultivate African human capital and entrepreneurial potential as a viable alternative to FDI. The international economic forces that drive FDI are not well suited to securing 
the underlying determinants that would enable the continent achieve the health targets of SDG 3. Strengthening local capital and enterprise as an alternative to FDI offers a better chance for the continent to get it right with health in the agenda of the SDGs.

TWAIL's broad geography and decentralised network (Gathii 2011) is useful for challenging assumptions about the way issues affecting Africa (and other states in the global south) are perceived by the rest of the world. This is particularly true in the area of health where the issues that bedevil the continent stem from deeply rooted power inequalities and structural asymmetries that characterise and define the engagement of international law, international institutions, and the developed countries of the global North with the countries of Africa and others in the global South.

FDI is not well suited to enable African states achieve the health targets of SDG 3: the weakness of African states when negotiating FDI terms; policy and non-policy factors that hinder many from attracting FDI inflow; and the inability of FDI inflow to translate to human capital development are among the factors to be considered. We make the case for cultivating African human capital and entrepreneurial potentials as an alternative to FDI, and suggest that strengthening local capital as an alternative to FDI would create the necessary conditions for the underlying determinants of health to flourish. The SDGs 2030 offer the African continent another unique opportunity to lay an enduring foundation for real progress in the area of health - if the continent looks beyond quick-fixes and develops enduring strategies for achieving the health targets of the SDGs.

\section{The Relevance of TWAIL}

Because of its refusal to take international law claims of universality at face-value, TWAIL offers a useful critical lens for this analysis. TWAIL's sceptical interrogation of the encounter of international law and international institutions with countries of the third world (or sometimes below, "global south") is not a particularly new tradition of "critical internationalism" (Okafor \& Ngwaba 2014, p. 91). Its intellectual roots stretch back to the Afro-Asian anti-colonial struggles of the 1940s-1960s, and even further back to the Latin American decolonisation movements. In its renaissance, contemporary TWAIL scholarship has engaged strongly with other critical schools of international legal scholarship (Okafor 2005). TWAIL scholars deploy a wide range of "analytic techniques/sensibilities in providing alternative approaches that 'assail the creation and perpetuation of international law' that subordinates the third world in the global legal order" (Okafor \& Ngwaba 2014, p. 92). 
TWAIL scholars aim to challenge the established orthodoxy about the way international law, institutions, thoughts and actions affect the South. Okafor observes that,

the TWAIL movement within the discipline of international legal studies is best viewed as a broad dialectic (or large umbrella) of opposition to the generally unequal, unfair and unjust character of an international legal regime that all-toooften (but not always) helps subjugate the Third World to domination, subordination, and serious disadvantage (Okafor 2005, p. 176 ).

Despite the lack of unanimity within its ranks (see for instance Chimni 2003; Ngugi 2001), TWAIL scholars are solidly united behind a "shared ethical commitment to the intellectual and practical struggle to expose, reform, or even retrench those features of the international legal system that help create or maintain the generally unequal, unfair, or unjust global order" (Okafor 2005, p. 177). TWAIL allows the interrogation of how international thought and action in the context of FDI has perpetuated existing "global power matrices and asymmetries" (Okafor \& Ngwaba, 2017) in the flow of trade and investment into Africa; and how, as a result, many African citizens have not been economically advantaged to reap the benefits of foreign trade. TWAIL also allows us to reconstruct our approaches to the health-related SDGs with a shift in emphasis from clinical care to the underlying determinants of health, where all too often the barriers to better health outcomes are deeply rooted.

The north/south dichotomy used in this article draws from TWAILIAN sensibilities. TWAILIAN discourse maps the geography of the South not in terms of any specific location, but in the way international law impacts "the governed, no matter where they are spatially located" (Eslava \& Pahuja 2012, p. 197).

\section{Can FDI Achieve the Health Targets of the SDGs?}

Contrary to what may appear to be common wisdom, FDI does not offer the best chance for African states to sustainably achieve the health targets of the SDGs. A number of factors, inherent in the character and orientation of the international economic forces and interests that drive FDI, inform this view. African states share the experience of significant weakness of negotiating position when hashing out terms of foreign investment agreements. International thought and action in the context of FDI has not 
been framed in a way that secures a strong negotiating position for African states. FDI flows in very competitive environments, and investment-seeking states have to demonstrate a significant degree of attractiveness to compete favourably (Anyanwu 2012). In determining a state's attractiveness, a range of considerations are taken into account including policy factors such openness, product-market regulation, labour market arrangements, corporate tax rates, FDI restrictions, trade barriers, and infrastructure (Fedderke \& Romm 2006) and non-policy factors such as market size of the investmentseeking state (often measured by GDP), distance/transport costs, political and economic stability (Mateev 2009) and natural resources (Asiedu 2006). Given these considerations, many African states have been compelled to make significant concessions, often to the detriment of their negotiating position, in an effort to remain attractive as FDI destinations. Investor-states on their part, taking advantage of these concessions, have milked investmentseeking states on the African continent for the most profitable deals. Through these, the losers have been the citizenry who have been deprived of real opportunities for achieving sustainable, all-inclusive economic growth.

Policy factors certainly raise issues that ought to be addressed by African states in order to be attractive for business (not just FDI). Infrastructure and trade barriers, amongst others factors, need to be addressed. More specifically, the issue of openness feeds into the problem of corruption which Anyanwu and others identify as a barrier to FDI inflow (Anyanwu 2012, p. 435; Voyager \& Beamish 2004; Zhao, Kim \& Du 2003). Anecdotal evidence suggests that corruption by government officials in the scramble for FDI has short-changed many African states by depriving them of critical resources required for development. Yet the extent to which corruption hinders FDI inflow is debatable. As suggested by Kim, countries with high levels of corruption of government and low levels of democracy have higher FDI inflows than countries with greater political rights (Kim 2010). This implies that corruption may be a hindrance, but it is not such a big hindrance. It is suggested here that corruption may in fact serve as a catalyst for unscrupulous foreign investors to operate on the continent with minimal levels of accountability, with the consequence that African people are deprived of vital resources required for human capital development.

Additionally, non-policy factors such as natural resources and size of the market are major determinants of the direction of FDI flows. The works of Asiedu $(2002,2006)$ and Deichman et al. (2003) show that the availability of natural resources has a positive and significant effect on FDI inflows. This perception is consistent with the data presented by the World Investment Report showing Angola, Nigeria, South Africa, Ghana, Ethiopia, 
Mozambique and Congo, respectively, as the top FDI destinations on the Africa continent between 1990 and 2016 inclusive (United Nations Conference on Trade and Development, 2017). This is problematic for three reasons identified by Asiedu. First, it suggests that FDI inflow to Africa is largely determined by an uncontrollable factor - the availability of natural resources - and that natural resource-poor countries will attract very little or no FDI, regardless of the policies implemented by the country; second, many countries in Africa have small markets (by GDP size) and are thus unattractive; and third, FDI flows in resource-rich countries are concentrated in natural resources, and investments in such industries do not generate the positive spillovers (such as technological transfer and employment creation) that are commonly associated with FDI (Asiedu 2006, p. 64).

Despite the very positive financial benefits said to be offered by FDI, the lasting benefit of human capital development (Reiter \& Steensma 2010) continues to elude many African states that are simply not competitive enough to attract FDI inflow. For those states that do attract FDI, a concentration of this inflow in the natural resources sector of the economy where technology is complex and difficult to transfer-means that spillover benefits that ordinarily should follow for the population have not followed. This translates to poor human capital development for many African states. The real economic cost of this state of affairs is seen in the continued impoverishment of the population of many African states; their place in history has been limited to witnessing the plunder of their country's natural resources by foreign investors aided by corrupt government officials.

For African states to experience real improvements in the state of health outcomes in their respective domains, they need to re-imagine the role they expect FDI to play in securing a better future for their population. Well harnessed, FDI can lead to the improvement of health capabilities (Ruger 2006) by bringing about improvements to the underlying determinants of health such as housing, food and nutrition, water, and the environment. Nonetheless, the brand of FDI that has taken hold on the African continent offers little in this regard, and this reality is the impulse for the cultivation of African human capital and entrepreneurial potential as an alternative paradigm to FDI. That can create the right conditions for sustainable, inclusive economic growth and in turn strengthen the underlying determinants of health across the continent.

\section{Cultivating African Human Capital and Entrepreneurial Potential}

The African continent is known for the abundance of its natural resources. Recently, however, it has gained recognition for its growing youthful 
population, with the population of the continent set to double by 2050 (United Nations 2017, p. 3). Yet, indices reveal untapped human capital and entrepreneurial potentials. As a 2014 Deloitte report tracking human capital trends on the continent shows, the continent is lagging behind in the development and engagement of the 21 st-century workforce (Deloitte 2014). The report, based on surveys carried out in fourteen African countries spread across the four key regional blocs of the continent, shows that the continent is lagging behind in the top four trends of leadership: retention and engagement; workforce capability; reskilling the HR function; and talent acquisition and access (Deloitte 2014, p. 8).

For entrepreneurship, the right conditions remain to be created to encourage Africa's youthful populace to lead the way in the marketplace of ideas and innovation. With increasing rates of unemployment spread across the continent, it is clear that cultivating the entrepreneurial potential of its youthful workforce is vital to guarantee the survival of the continent. The high unemployment rates recorded by a number of African countries in the 2018 UN Human Development Index point to the need for urgent action in this area. For instance, in Kenya, youth employment (persons between ages 15-25) was 26.2 per cent, while total unemployment rate in the labour force was 11.5 per cent. Nigeria's youth unemployment rate in the same period was 13.4 per cent and the labour force unemployment rate 7.0 per cent. South Africa and Tunisia recorded more alarming unemployment rates than Kenya and Nigeria. South Africa's youth employment rate was 57.4 per cent, with a labour force unemployment rate of 27.7 per cent. The Tunisian youth unemployment rate was 35.8 per cent, with labour force unemployment at 15.2 per cent (United Nations Development Programme 2018).

A focus on the unemployment rate draws attention to the imperative need for action by African states to cultivate the conditions that would enable the continent's human capital and entrepreneurial potentials to flourish. As the Ghanaian example demonstrates in the context of the Millennium Development Goals 2015 (MDGs), strong economic growth can lead to a dramatic fall in the poverty rate. Mainly on account of its strong economic performance since the early 1990s, accelerating into the last decade, Ghana was able to achieve significant milestones in terms poverty reduction and improvements in health outcomes. Ghana met the MDGs target of halving poverty ahead of the target period, with the share of the population living in poverty decreasing from 52 per cent in 1991 to 24 per cent in 2012 (Ghana Statistical Service 2014a; Molini and Paci 2015). Significant progress was also made in health, education, and other areas important to individual and social well-being (Honorati \& de Silva 2016, p. 1). 
As previously argued, focusing on the cultivation of African human capital and entrepreneurship would create the right conditions for the underlying determinants of health to flourish. It has also been suggested that this would offer African states a better chance to achieve the health targets of SDG 3. But how, exactly, are the health targets of SDG 3 linked to the underlying determinants of health? And why has it been suggested that focusing on human capital and entrepreneurship would offer a better chance for African states to achieve the health targets of SDG 3 ?

\section{The link between SDG 3 and underlying determinants of health}

The goal of SDG 3 is to "ensure healthy lives and promote well-being for all at all ages." Thirteen health targets have been identified in achieving this goal, namely: reducing the global mortality ratio to less than 70 per 100,000 live births; ending preventable deaths of newborns and children under five years as well as reducing neonatal mortality; ending the epidemics of AIDS, tuberculosis, malaria and neglected tropical diseases whilst combating hepatitis, water-borne diseases and other communicable diseases; reducing by one third premature mortality from communicable diseases through prevention and treatment, and promoting mental health and well-being; strengthening the prevention and treatment of substance abuse; halving the number of deaths and injuries from road traffic accidents; ensuring universal access to sexual and reproductive health-care services; achieving universal health coverage, financial risk protection, access to quality essential healthcare services, and access to safe, effective, quality and affordable essential medicines and vaccines for all; substantially reducing the number of deaths and illnesses from hazardous chemicals and air, water and soil pollution and contamination; strengthening the implementation of the WHO Framework Convention on Tobacco Control in all countries; supporting research and development of vaccines and medicines for communicable and noncommunicable diseases that primarily affect developing countries, and providing access to affordable essential medicines and vaccines in accordance with the Doha Declaration on the TRIPS Agreement and Public Health; substantially increasing health financing, recruitment, development, training and retention of the health workforce in developing countries, especially the least developed countries and small island developing states; and strengthening the capacity of all countries, in particular developing countries, for early warning, risk reduction and management of national and global health risks (WHO 2019). All of these targets are to be achieved by 2030, according to SDG 3. It is clear that while some of these targets require measures to be taken that involve other spheres of governance beyond health, 
many others are directly connected to health and the well-being of the populace.

The reference to well-being in SDG 3 re-echoes the definition of health in WHO Constitution as "... a state of complete physical, mental and social well-being and not merely the absence of disease or infirmity" (WHO Constitution 1946). Successive international human rights instruments, such as the International Covenant on Economic, Social and Cultural Rights (ICESCR), amongst others, have built on this understanding of health in the iteration of the right to health (see article 12 ICESCR). The interpretative jurisprudence of the Committee on Economic, Social and Cultural Right (CESCR) has done much to clarify the exact contours of the right to health as comprising the underlying determinants of health. Thus CESCR noted that the Third Committee of the United Nations General Assembly did not adopt the definition of health contained in the 1946 preamble (above) but did observe that the reference in article 12.1 of the Covenant to the "highest attainable standard of physical and mental health" was not confined to the right to health care. On the contrary, the wording of article 12.2 acknowledges that the right to health embraces a wide range of socioeconomic factors that promote conditions in which people can lead a healthy life, and extends to the underlying determinants of health, such as food and nutrition, housing, access to safe and potable water and adequate sanitation, safe and healthy working conditions, and a healthy environment (CESCR 2000, para. 4).

It is hardly debatable that these factors, outlined as the underlying determinants of health, require economically self-sufficient conditions to be created for the populace of African states. It is hard to imagine how the population of African states can achieve these underlying determinants of health without equally achieving economic self-sufficiency. As argued above, the foundational premise underpinning SDG 3 is the notion of achieving well-being (for an interesting discussion of this concept see Callahan, 1973). When we pry deeper into what that means, we encounter the jurisprudence of the right to health in international law, where this concept derives its provenance. This jurisprudence informs us that the underlying determinants of health lie at the foundation of SDG 3. Thus, African states need to ensure that in developing strategies to achieve the health targets of SDG 3, they are also paying attention to creating the right conditions for sustainable, all-inclusive economic growth that can strengthen the underlying determinants of health in the continent. 


\section{The promise from cultivating African human capital and entrepreneurial potentials}

The central thesis advanced here is that cultivating African human capital and entrepreneurship offers the best chance for African states to sustainably achieve the health targets of SDG 3. What remains is to identify the basis of the appeal to cultivating African human capital and entrepreneurship over dependence on FDI. The undergirding principle here is "sustainability". The strategy of African states should be sustainable lest it defeats the objectives of the SDGs which give a pre-eminent place to sustainable development. Three reasons are identified as supporting the case for cultivating African human capital and entrepreneurship (and thus informing its appeal over FDI).

Bearing in mind the international economic interests and profit-oriented motives that inform the decision to invest foreign capital by investors from the north in countries of the south (to borrow from Twailian sensibilities), it is unsustainable to expect to achieve the health targets of SDG 3 on the promise of FDI inflow. As noted, many challenges hinder the inflow of FDI into many African states. Some of the challenges mentioned in the literature speak to the issue of the divergence of interests between investor-states and investor-seeking states that often result to investor-seeking states making detrimental concessions to attract foreign investments. This is so because in the "race to the bottom" that characterises FDI praxis in the global south, the investor is king and whatever he/she desires, almost always, must be fulfilled.

Real economic growth cannot take place without a clear policy of the state that impacts a large segment of the populace. As Ghana's example illustrates, there is a clear link between strong economic growth and a decline in the poverty rate, which in turn translates to the attainment of the underlying determinants of health. There is a clear pathway to achieving the health targets of SDG 3 if a well framed policy is put in place to grow the economy and lift as many people as possible out of poverty in African states. A policy that focuses on cultivating African human capital and entrepreneurship is argued to be more likely to offer a similar outcome (as experienced by Ghana) as opposed to one whose main strategy is to attract FDI inflow in the hope that the gains recorded from FDI (if at all) will trickle down to the populace and improve the underlying determinants of health.

Given available data from the Global Entrepreneurship Monitor (GEM), Africa is alive with entrepreneurial potentials that are waiting to be harnessed. GEM's data provide a positive outlook on the total early-stage entrepreneurial activity (TEA), as well as the entrepreneurial intentions rate (EIR) in a number of African countries. The TEA rate measures the percentage of the population (18-64 years) who are either nascent entrepreneurs or owner- 
managers of a new business; the EIR measures the percentage of the population (18-64 years) who are latent entrepreneurs and who intend to start a business within three years, excluding individuals involved in any stage of entrepreneurial activity (Disrupt Africa 2017). The data sets are quite promising, regardless of the part of the continent being considered. For instance, Tunisia in 2015 had a TEA rate of 10.13 per cent (global average 13.22 per cent); and an EIR rate of 28.80 per cent (global average 21.78 per cent) (GEM 2015). South Africa, with more recent data from 2017, had a TEA rate of 10.96 per cent (global average 12.46 per cent); and an EIR rate of 11.72 per cent (global average 21.66 per cent) (GEM 2017). In Uganda, the most recent data from 2014 showed a TEA rate of 35.53 per cent (global average 13.08 per cent); and an EIR rate of 60.72 per cent (global average 20.94 per cent) (GEM 2014). In Nigeria, the most recent data from 2013 showed a TEA rate of 39.86 per cent (global average 13.55 per cent); and an EIR rate of 46.81 per cent (global average 24.22 per cent) (GEM 2013).

The data suggest that there is much unharnessed potential for entrepreneurship on the African continent. As the figures for Nigeria, Uganda and Tunisia show, those with entrepreneurial intentions in these countries are above the global average. This provides a strong rationale for the case to cultivate these potential entrepreneurs to grow the economy, whilst helping to create the right conditions that will see to the improvements in the underlying determinants of health in these African states.

\section{Conclusion}

SDG 3 offers African states another unique opportunity to lay an enduring foundation for real progress in the area of health. But the governments of the continent need to look beyond quick-fixes, and develop enduring strategies for achieving the health targets of SDG 3. This is the premise for the argument advanced here that cultivating African human capital and entrepreneurship offers the best chance for African states to sustainably achieve the health targets of SDG 3. The sceptical lens of Twailian discourse suggested that the international economic interests and forces (mostly from the global North) that drive FDI inflow on the African continent are not organised in a manner that supports the sustainable development of African states, particularly in the area of health. Given the self-serving interests that often drive FDI inflow, it is unsustainable to expect FDI to be the best chance to achieve the health targets discussed above when many of the benefits that come through FDI are not transferrable to the African continent through human capital development. As the data sets from GEM show, many African states have entrepreneurial potentials waiting to be harnessed through the 
adoption of appropriate government policies. FDI does not represent Africa's best chance to sustainably achieve the health targets of SDG 3. Africa's best chance lies in the cultivation of African human capital and entrepreneurial potentials.

\section{References}

Anyanwu, J. C. (2012). Why Does Foreign Direct Investment Go Where it Goes?: New Evidence from African Countries. Annals of Economics and Finance, 13(2), 425-462.

Asiedu, E. (2002). On the Determinants of Foriegn Direct Investment to Developing Countries: Is Africa Different? World Development, 30(1), 107-109.

Asiedu, E. (2006). Foreign Direct Investment in Africa: The Role of Natural Resources, Market Size, Government Policy, Institutions and Political Instability. The World Economy, 29(1), 63-77.

Callahan, D. (1973). The WHO Definition of Health. The Hastings Center Studies, 1(3), 77.

Chimni, B. (2003). Third World Approaches to International Law: A Manifesto. In A. A. e. al. (Ed.), The Third World and International Order: Law, Politics and Globalization. Leiden: Martinus Nijhoff.

Deichmann, J. I., Eshghi, A., Haughton, D. M., Selin, S., \& Teebagy, N. C. (2003). Foreign Direct Investment in the Eurasian Transition States. Estern European Economics, 41(4), 5-34.

Deloitte. (2014). Africa Human Capital Trends 2014: Engaging the $21^{\text {st }}$ Century Workforce. Retrieved from https://www2.deloitte.com/content/dam/Deloitte/global/Documents/ HumanCapital/dttl-human-capital-trends-africa.pdf

Disrupt Africa. (27 July 2017). Cultivating A Culture of Entrepreneurship in Africa. Retrieved from http://disrupt-africa.com/2017/07/cultivatinga-culture-of-entrepreneurship-in-africa/

Eslava, L., \& Pahuja, S. (2012). Beyond the (Post)Colonial: TWAIL and the Everyday Life of International Law. Journal of Law and Politics in Africa, Asia and Latin America, 45(2), 195-221.

Fedderke, J., \& Romm, A. T. (2006). Growth Impact and Determinants of Foreign Direct Investment into South Africa, 1956-2003. Economic Modeling, 23, 738-760.

Forman, L. (2016). What do Core Obligations Under the Right to Health Bring to Universal Health Coverage? Health and Human Rights Journal, 18(2), 23. 
Gathii, J. T. (2011). TWAIL: A Brief History of Its Origins, Its Decentralized Network, and a Tentative Bibliography. Trade Law and Development, 26, 26-64.

Global Entrepreneurship Monitor. (2013). Nigeria: Entrepreneurial Behaviour and Attitudes. https://www.gemconsortium.org/countryprofile/93

Global Entrepreneurship Monitor. (2017). South Africa: Entrepreneurial Behaviour and Attitudes. https://www.gemconsortium.org/countryprofile/108

Global Entrepreneurship Monitor. (2015). Tunisia: Entrepreneurial Behaviour and Attitudes. https://www.gemconsortium.org/countryprofile/123

Global Entrepreneurship Monitor. (2014). Uganda: Entrepreneurial Behaviour and Attitudes. https://www.gemconsortium.org/countryprofile/117

Ghana Statistical Service. (2014a). Poverty Profile in Ghana (2005-2013). Accra, Ghana (August).

Honorati, M., \& de Silva, S. J. (2016). Expanding Job Opportunities in Ghana. Washington, DC: World Bank.

Kim, H. (2010). Political Stability and Foreign Direct Investment. International Journal of Economics and Finance, 2(3), 59-71.

Mateev, M. (2009). Determinants of Foreign Direct Investment in Central and Southeastern Europe: New Empirical Tests. Oxford Journal, 8(1), 133-149.

Molini, V., \& Paci, P. (2015). Poverty Reduction in Ghana: Progress and Challenges. Washington, DC: World Bank.

Mutua, M. (2000). What is TWAIL? Paper presented at the Americian Society of International Law Proceedings, Washington DC.

Ngugi, J. (2002). Making New Wine for Old Wineskins: Can the Reform of International Law Emancipate the Third World in the Age of Globalization? UC Davis Journal of International Law and Policy, 8, 73-106.

Okafor, O. C. (2005). Newness, Imperialism, and International Legal Reform in Our Time: A Twail Perspective Osgoode Hall Law Journal, 43(1/2), 171-191.

Okafor, O. C., \& Ngwaba, U. (2014). The International Criminal Court as a 'Transitional Justice' Mechanism in Africa: Some Critical Reflections. International Journal of Transitional Justice, 9(1), 90-108.

Okafor, O. C., \& Ngwaba, U. (2017). Between Tunnel Vision and Sliding Scale: Power, Normativity and Justice in the Praxis of the 
International Criminal Court. Temple International \& Comparative Law Journal, 31(1), 179-193.

Ooms, G., Brolan, C., Eggermont, N., Eide, A., Flores, W., Forman, L., . . . Jahn, A. (2013). Universal Health Coverage Anchored in the Right to Health. Bulletin of the World Health Organization, 91(2-2A), 1.

Reiter, S. L., \& Steensma, K. H. (2010). Human Development and Foreign

Direct Investment in Developing Countries: The Influence of FDI Policy and Corruption. World Development, 38(12), 1678-1691.

Ruger, J. P. (2006). Towards a Theory of a Right to Health: Capability and Incompletely Theorized Agreements. Yale Law Journal of Law \& the Humanities, 18(2), 273-326.

United Nations Conference on Trade and Development. (2017, 07 June 2017). World Investment Report: Annex Tables. Retrieved from http://unctad.org/en/Pages/DIAE/World Investment Report/AnnexTables.aspx

United Nations. (2017). World Population Prospects The 2017 Revision: Key Findings and Advance Tables. https://esa.un.org/unpd/wpp/ publications/files/wpp2017 keyfindings.pdf

United Nations, Office of the High Commissioner for Human Rights. (2000). CESCR General Comment No. 14: The Right to the Highest Attainable Standard of Health. http://www.refworld.org/ pdfid/4538838d0.pdf

United Nations Development Programme. (2018). Human Development Reports: Kenya. http://hdr.undp.org/en/countries/profiles/KEN

United Nations Development Programme. (2018). Human Development

Reports: Nigeria. http://hdr.undp.org/en/countries/profiles/NGA

United Nations Development Programme. (2018). Human Development Reports: South Africa. http://hdr.undp.org/en/countries/profiles/ZAF

United Nations Development Programme. (2018). Human Development Reports: Tunisia. http://hdr.undp.org/en/countries/profiles/TUN United Nations, Office of the High Commissioner for Human Rights. (2000). CESCR General Comment No. 14: The Right to the Highest Attainable Standard of Health. http://www.refworld.org/pdfid/4538838d0.pdf

Voyager, P. A., \& Beamish, P. W. (2004). The Effect of Corruption on Japanese Foreign Direct Investment. Journal of Business Ethics, 50, 211-224.

World Health Organanisation. (1946). Constitution of the World Health Organisation. http://apps.who.int/gb/bd/PDF/bd47/EN/constitutionen.pdf?ua $=1$ 
World Health Organisation. (2019). SDG 3: Ensure healthy lives and promote wellbeing for all at all ages https://www.who.int/ sdg/targets/en/

World Health Organisation. (2014). Millennium Development Goals (MDGs). www.who.int/topics/millennium development goals/en/

World Health Organisation. (2015). Health in 2015: From MDGs, Millennium Development Goals to SDGs, Sustainable Development Goals: World Health Organisation.

World Health Organisation and United Nations Children's Fund. (1978). Primary Health Care. Alma Ata 1978. www.unicef.org/ about/history/files/Alma_Ata_conference_1978_report.pdf

Zhao, J. H., Kim, S. H., \& Du, J. (2003). The Impact of Corruption and Transparency on Foreign Direct Investment: An Empirical Analysis. Management International Review, 43(1), 41-62. 